\title{
Debunking the Latest Scenario on the Rise of the Pork Taboo
}

\author{
Philippe Guillaume
}

\begin{abstract}
A number of studies from Tel Aviv date the rise of the pork taboo in Israel as early as the Iron Age I in order to salvage the notion that the taboo was a reaction to the pork-consuming habits of the hated Philistines. Though neither DNA analysis nor pig bone ratios support this scenario, these studies explain how the abhorrence of Iron Age Israelites for pork was eventually canonised in the Persian era. The present paper challenges the validity of each stage of the proposed scenario, arguing that the Hellenistic-era ethnic differentiation based on pork consumption cannot be pushed as far back as the Iron Age.
\end{abstract}

Keywords: pigs, pork taboo, Sus, ethnicity, Iron Age Palestine, Neo-Assyrian Empire

Philippe Guillaume, Institut für Bibelwissenschaft, University of Berne, Berne; philippe.guillaume@gmail.com

Much has been written about why pigs are not kosher (Lev 11:7; Deut 14:8). Pigs are supposedly ill adapted to the Judean climate, they are infested with worms, they occupy the same place on the food chain as humans, ${ }^{1}$ or they are unsuited to a nomadic life-style which most probably explains why not a single pig is listed besides the thousands of other animals recorded on the Banquet Stele of Aššurnașirpal II. ${ }^{2}$ Other explanations focus on what pigs do not produce. Producing no milk, no wool, no traction and only poor-quality leather, pigs played no role in the 'Secondary Products Revolution'. ${ }^{3}$ As this revolution occurred well over two millennia before the rise of the biblical ban, it is clear that humans had other reasons to find pigs useful.

Often cited in theological circles to explain the rise of the pork taboo, Mary Douglas declared the pig carrier of the odium of multiple pollutions. First it pollutes because it defies the classification of ungulates. Second, it pollutes because it eats carrion. Third,

1 Harris 1977: 162; Sasson 2010: 70.

2 Grayson 1991: 175-76. Foster and Salgues (2006: 290) argue that the absence of pork on the menu is due to the fact that Aššurnașirpal (883-859 BCE) ruled during and after a period of major Aramean presence in Mesopotamia.

3 Sherratt 1981; Poplin 2006; Sasson, Greenfield 2014. 
it pollutes because it is reared by non-Israelites. ${ }^{4}$ To Douglas' indictment, Nicole Ruane adds another level of pollution: the pig pollutes because it represents a grotesque form of reproduction offensive to biblical society and thought. ${ }^{5}$

The quest of causes for the biblical ban continues because in the face of millennia of pork consumption around the globe, the pig has served humans well, and continues to do so. Notions of pollution are a postiori justifications of the biblical taboo but fail to identify the causes for its rise. Biological explanations are no more convincing than symbolic ones.

Pigs are in fact one of the most adaptable species of mammals and thrive under most climates. The main threat for wild pigs is deep snow, conditions that are too rare to threaten them in the Levant. ${ }^{6}$ Pigs thrive in hot climates, even in arid environments such as the south of the Dead Sea, the Egyptian desert, in the Northern Negev and South Jordanian Tawilan. ${ }^{7}$ The availability of water is indeed an important factor, not as is commonly thought for the survival of pigs, but for the type of natural environment which makes pig-husbandary a viable option for humans. As for worms, all mammals host them, including humans. The thriving demography of pork-eating China should be enough to discount the actual effect of pig-related worms to human health.

Political reasons have also been advanced. The pork taboo was thought to have been imposed first by the Egyptian crown to tighten its grip over peasants of peripheral areas whose pork consumption supposedly guaranteed them a level of autonomy which made them unruly. ${ }^{8}$ Pigs, however, never seem to have been bred in a peripheral area such as the Hijaz, but in China pork consumption exists side by side with a strong central government. ${ }^{9}$ As pork-abstaining nomads do not start eating pork once they settle, religion is a major factor in the rise of the pork taboo, though this begs the question as to why would a religion make such a precious source of proteins taboo. ${ }^{10}$

\section{ARCHAEOLOGY AT THE RESCUE}

\section{MitOCHONDRIAL DNA}

Recent research made at the Weizmann Institute of Science in Israel presents new insights regarding the origin of pigs in the Levant. A study of DNA sought to determine whether or not the arrival of European pigs in the Levant could be tied to the migration of the Sea People and the coming of the Philistines..$^{11}$ The appearance of European pigs in the Levant at about the same time as the Philistines would support the ethnic scenario, according to which the biblical taboo represents the reaction of Israelite population to the arrival

\footnotetext{
4 Douglas 1975: 272.

5 Ruane 2015: 492-93.

6 Nowak 1999.

7 Mendelssohn, Yom-Tov 1999; Hamilton-Dyer 2001: 267; Sade 1988; Köhler-Rollefson 1995.

8 Diebner, Robkin 1978.

9 Henninger 1982.

10 Hocine Benkheira 2006.

11 Meiri et al. 2013: 6.
} 
of pork-eating Philistines. The validity of this scenario was disputed in 2002 and the question now is whether or not new data can disprove Brian Hesse and Paula Wapnish's resistance. $^{12}$

The study concludes that European pigs arrived both in Anatolia and in the southern Levant in the Iron Age, though it admits that there is a 250-year gap between the purported coming of the Philistines and the first European mitochondrial DNA signal. The authors of the study also concede that they cannot refute the possibility that European pigs were brought to the southern Levant already in the Bronze Age, because the crucial sample from Middle Bronze Ashkelon could not be radio-carbon dated and may be intrusive. Nevertheless, the publication claims that a major shift between Near Eastern to European haplotypes took place around $900 \mathrm{BCE}$ in the southern Levant. To maintain the connection to the migration of the Sea Peoples, the following qualifications are introduced:

1. the Sea Peoples' migration was a several-decades-long process;

2. most of the Iron Age samples come from non-Sea Peoples sites;

3. the sample-size is too small to track minute chronological processes within the early phases of the Iron Age;

4. it took some time for the haplotype to become significant. ${ }^{13}$

In fact, the several decades of the purported Sea People migration turn out to be a twocentury process during which many things happened besides the arrival of the so-called Sea People. That such a study uses the notion of 'Sea People sites' is surprising since the article states that the distribution of Philistine pottery indicates at least cultural diffusion to broader areas of the region, beyond the coast of the Levant, e.g., to the north and inland of the Levant. ${ }^{14}$ Hence, besides the limited size of the sample, which prevents tracking when in the Iron Age European pigs arrived in the Levant, the study cannot confirm the link between the arrival of European pigs and the Philistines.

The application of hard sciences in the debate is a most welcome move as it introduces data which is less easily manipulated than is the case in social sciences. Impressive as it is, the study of mitochondrial DNA cannot prove or disprove the notion that the biblical pork taboo was a reaction to the arrival of the Philistines in the Levantine coast.

\section{Pig BONES RATIOS}

More relevant to the ethnic scenario, another Israeli study financed by the same European grant as the above study, presents a most useful synthesis of data from excavations of the last twenty years. ${ }^{15}$ The paper presents the relevant data provided in this study in Tab. $\mathbf{1}$.

\footnotetext{
12 Hesse, Wapnish 2002: 469.

13 Meiri et al. 2013: 6.

14 Meiri et al. 2013: 6.

15 Sapir-Hen et al. 2013: 11-12. See also: Sapir et al. 2015.
} 
Tab 1. Pig bones ratios by region and period

\begin{tabular}{|c|c|c|c|c|c|}
\hline Iron Age & Judah & $\begin{array}{c}\text { Urban coastal } \\
\text { sites }\end{array}$ & $\begin{array}{c}\text { Rural coastal } \\
\text { sites }\end{array}$ & $\begin{array}{c}\text { Lowland } \\
\text { Israelite sites }\end{array}$ & $\begin{array}{c}\text { Highland } \\
\text { Israelite sites }\end{array}$ \\
\hline I & low & high & low & low & low \\
\hline IIA-B & low & high & $?$ & high & $?$ \\
\hline IIC & low & drastic decrease & low & $?$ & $?$ \\
\hline Persian & $?$ & $?$ & $?$ & $?$ & $?$ \\
\hline
\end{tabular}

Differences in pig bone ratios appear between urban and rural sites in the coastal lowland and between Judahite and Northern Israelite sites in the Iron Age IIB:

- three non-urban settlements within the presumed territory of the Philistine city-states have no or very few pig bones: only $0.4 \%$ at Aphek, $1.2 \%$ at Tell Qasile in northern Philistia, and no pig bones in Qubur el-Waleyide near Gaza;

- Lowland sites in the presumed Israelite kingdom of the Iron Age IIB have relatively high pig bones ratios: Beth-Shean 7.5\%, Megiddo 7.5\%, and Yoqneam 5\%.

Logically, the discussion of the archaeological data concludes that correlating pork consumption and avoidance with cultural differentiation processes between the Philistines and the "others", be they Israelite or Canaanite, is somewhat insecure. ${ }^{16}$ Insecure as it is, abstinence from pork is nevertheless restated as a valid ethnic marker in the concluding paragraph of the article: Pig taboo could have emerged in the highlands - in the north and in the south where as a result of the pastoral background of many of the Iron Age I settlers and the need to create a "we"-and- "they" boundary with the Philistines in the southern lowlands. ${ }^{17}$

This conclusion is not supported by the data discussed in the study itself. A more obvious conclusion would focus on differences between rural and urban sites as well as between coastal and highland sites rather than maintaining the distinction between Philistines and others, a distinction that the above DNA study could not confirm. What the correlation of pig bone ratios does indicate is that rural sites in Iron Age I Philistia display similar ratios to highland sites of the period. Therefore, the validity of pork consumption as an ethnic marker is seriously undermined. To avoid this conclusion, two of Israel Finkelstein's hypotheses are recruited to shore up an ethnic cause for the rise of the biblical pork taboo: a population explosion in Iron Age II northern Israel and a flood of Israelite refugees in Judah in the wake of the Assyrian conquests. The scenario for the rise of the pork taboo is reconstructed in four phases:

1. Pork avoidance emerged in the Iron Age I when highland settlers felt the need to create a boundary with the Philistines.

2. In the Iron Age II, Israelites had to start eating pork as the population explosion reduced pasturing grounds to the point that there was not enough space to graze sheep and goat.

\footnotetext{
16 Sapir-Hen et al. 2013: 11.

17 Sapir-Hen et al. 2013: 13.
} 
3. Upon the collapse of the Northern Kingdom, Israelite refugees fled to Judah where their pork eating habit was frowned upon by Judahite rulers who aspired to rule the territories of the ex-Northern Kingdom. Concern over the pork consumption of the Israelite refugees became more acute when Josiah sought to extend Jerusalem's rule over the territories of the Assyrian province of Samaria.

4. The pork consumption habits of these Israelite refugees remained acute enough in the eyes of Judeans to spur the biblical pork taboo in the Persian era when the pork taboo became a Judahite cultural trait the biblical authors wished to impose on the entire Israelite population.

This impressive reconstruction finds little support in the up-to-date zooarchaeological results gathered by the study itself. Instead, it fills gaps with hypotheses that have been repeatedly discussed by other scholars and found wanting.

The gaps are due to the fact that zooarchaeology is still in its infancy: The routine collection of animal remains from sites of the Bronze Age and later in the Levant is only a recent development. ${ }^{18}$ As indicated in Tab. 1, the study ignores the few (and admittedly quite insignificant) results from Persian era sites. ${ }^{19}$ The dearth of Persian era data is a major problem if the pork taboo was committed to writing during Achaemenid rule, as stage 4 argues. Also lacking is data for Iron Age IIB Israelite sites in the highland, precisely when lowland Israelite cities display an increase of pig bones. ${ }^{20}$ This prevents any comparison between the two sectors of the Kingdom of Israel. For the Iron Age I, the pork-loving trait of the Philistines is only based on pig bone ratios from Gath and Ekron. Most of the data from Ashkelon is forthcoming, ${ }^{21}$ the excavations at Ashdod did not collect enough bones and Gaza is off-limits. Besides the limitations of the archaeological data, several components of the historical reconstruction are disputable. The case requires a detour to consider the notion of ethnicity which underlies the search of a distinct Israelite identity in the Iron Age I.

\section{THE SHAKY PILlars of ISRAELITE ETHNOGENESIS IN THE IRON Age I}

If the pig taboo emerged in the highlands - in the north and in the south - as a result of the pastoral background of many of the Iron Age I settlers, ${ }^{22}$ the Philistine factor becomes irrelevant to the rise of the pork taboo, all the more so since lowland rural sites display the same lack of pig bones as highland sites.

Moreover, 'pastoralism' is rather vague and in no way explains the rise of the biblical taboo. What rules out pig husbandry is long distance nomadism, a specific kind of nomadism that arose later than the Iron Age I. The short distance seasonal movement of flocks in

\footnotetext{
18 Hesse, Wapnish 2002: 460.

19 Hesse, Wapnish 2002: 489 has six Persian era entries (Yoqneam, Michal, Ashkelon, Jemmeh, Hesi and Halif).

20 Sapir-Hen et al. 2013: 11.

21 Hesse, Fulton, Wapnish 2011.

22 Sapir-Hen et al. 2013: 13.
} 
no way excludes rearing a few pigs around the home because settlements are not empty while the flocks are driven to distant pastures. Moreover, the ethnoarchaeological studies mentioned below reveal that pigs can be herded and driven over tens of kilometres to make the most of resources at different altitudes, exactly what transhumance pastoralism does. Therefore, the pastoral background of Iron Age I highlanders offers no explanation for the rise of the pork taboo.

The repetition of the notion of the rise of the pork taboo at the end of the study that does not support it springs not from analysis of the archaeological data but from the fact that pig bones are the last pillar upon which the existence of an Israelite ethnogenesis as early as the Iron Age I has been constructed. Hence the reluctance to give up pig bones as a valid marker of proto-Israelite ethnicity in the Iron Age I. Instead of drawing the conclusion that pork consumption did not differentiate Iron Age I highlanders from their contemporaries in small (Philistine?) coastal sites, the difference between pig bone ratios from a few Iron Age I lowland cities and the highland is restated to shore up by mere repetition the notion that pork consumption served as an ethnic marker with which protoIsraelites developed a separate identity. ${ }^{23}$

The other markers - four-room pillar houses, collared-rim jars and undecorated table ware - by which the highland population of the southern Levant supposedly signified their distinct Israelite identity - have all lost much significance despite the publications that keep repeating them. ${ }^{24}$ The distribution of four-room pillared houses and of collared-rim jars is far broader than the area occupied by ancient Israel (see below).

To salvage the validity of the four-room house, variations from the normative model are deemed local adaptations when they are found in what is considered Israelite territory, while they are rejected as not fitting the model when they do not deviate from the model but are found outside what is considered Israelite territory. Neither the number of rooms nor the presence of pillars are sufficient indicators, or they indicate the presence of Israelites in Transjordan. ${ }^{25}$

Another way to deal with four-room houses outside Israelite territory is to consider them irrelevant since most of them date to the Iron Age I, that is earlier than the final crystallization of ethnic groups in the land.${ }^{26}$ If the final crystallisation of Israelite ethnicity only occurred in the Iron Age II, the discussion of the other Philistine and Israelite ethnic markers in the Iron Age is irrelevant and the four-room house cannot be a marker of Israelite ethnicity before the end of the Iron Age I.

Therefore, pig bones ratios are now the last crutch to hold up the notion of Israelite ethnicity in the Iron Age I. The difference in the proportion of pig bones in faunal assemblages is declared the consequence of the hostile interaction between 'Philistines' and proto-Israelites: As the interaction between the groups intensified, they needed to stress

\footnotetext{
${ }^{23}$ Finkelstein 1988; 1997.

24 Stager 1995; Faust 2007; 2012; Joffe 1999.

25 Faust, Bunimovitz 2003: 30.

26 Faust, Bunimovitz 2003: 30 .
} 
and demarcate the differences between them, and as the process of boundary maintenance intensified, each group stressed the habits that were different from those of the other group..$^{27}$

Yet, a study published a year later by the same zooarchaeologist warns that the pork consumption criterion remains based on small sample sizes and only scant consideration of possible alternatives which may explain the perceived phenomenon. ${ }^{28}$ As this opinion agrees with the view that the correlation of pork consumption with cultural differentiation processes between the Philistines and others is insecure,${ }^{29}$ the pillar shoring up a distinctive Israelite identity as early as the Iron Age I is about to collapse. The reappearance of pig bone ratios as a valid ethnic marker in the conclusion of the article that deems them insecure compensates the lack of evidence by sheer repetition. ${ }^{30}$

Turning from archaeology to history, any discussion of the history of the kingdoms of the southern Levant has to start with the campaigns of Pharaoh Shoshenq. ${ }^{31}$ Before Shoshenq's journey in the southern Levant, the lack of sources prevents drawing a coherent picture of the relation between the various kingdoms of the region, and even more so whether some inhabitants hated pork because their neighbours loved ham. ${ }^{32}$ In fact, the biblical Philistines may well reflect seventh century BCE realities. ${ }^{33}$

To be sure, hints to realities earlier than the seventh century and even earlier than Shoshenq may still be found in the biblical text. The Book of Samuel reports Philistine garrisons in the highland, well beyond the geographic distribution of Philistine pottery: in Bethlehem (2 Sam 23:14), Gibeon (1 Sam 10:5; cf. 2 Sam 21:2) and possibly in Jerusalem (2 Sam 5:6-9.18-25). ${ }^{34}$ If high pig bone ratios are accepted as markers of Philistine identity resulting from the Aegean origins of the Philistines, terms of possible Aegean origin used in descriptions of the temple of Jerusalem such as לביר and can be taken as reflections of 'Philistine' influence too. Tellingly, these terms are not deemed foreign in the Hebrew Bible. ${ }^{35}$ Hence, there is no evidence of animosity between highland and lowland groups before Shoshenq, nor between the kingdoms of Judah and Gath in the tenth-ninth centuries BCE. ${ }^{36}$ In this case, the competition between Philistines and Judeans is built on sand. The verdict published ten years ago remains valid: the search for Israel's ancient ethnic identity is a strange one, since it almost always seems to presuppose an anachronistic form of national identity, assuming not only the congruence of a political territorial Israel and a communal social Israel, but also the persistence of such a congruence,

\footnotetext{
27 Faust, Lev-Tov 2011: 21.

28 Lev-Tov 2012: 597.

29 Sapir-Hen et al. 2013: 11.

30 Sapir-Hen et al. 2013: 13.

31 Wilson 2005; Finkelstein 2007.

32 Na'aman 2013: 265.

33 Finkelstein 2002.

34 Niesiołowski-Spanò 2013.

35 Niesiołowski-Spanò 2014.

$36 \mathrm{Na}$ 'aman 2013.
} 
an impossibility - to say nothing of the assumption of shared political identity between ruler and ruled. ${ }^{37}$

Continuing to promote pork consumption as an ethnic marker of Philistine culture is perilous. ${ }^{38}$ No help can be expected from biblical texts that are mute as to whether or not Israelites considered house plans, storage jars and table ware meaningful cultural traits. ${ }^{39}$ The texts only mention abstinence from pork, but not in relation to the Philistines who are designated as uncircumcised, never as pork-eaters. Circumcision is of course beyond archaeological scrutiny.

\section{ETHNICITY AS AN IMPERIAL PHENOMENON}

Another problem with the search for a specific Israelite or Judean ethnicity as early as the Iron Age I is that ethnicity seems to be a consequence of some forms of imperialism. ${ }^{40}$ Unless ethnicity is used as a ragbag for anything having to do with identity, 'ethnicity' ought to be reserved for social relationships structured around differences that are based on and communicated by commonly accepted markers of such differentiation..$^{41}$ One important marker is common descent, not actual biological descent but a socially constructed discourse of such descent. ${ }^{42}$ Related to descent are a shared past and a homeland associated with the group, though this does not imply political control of that territory. ${ }^{43}$

The low demographic levels in the Iron Age I are unlikely conditions for the rise of tensions between the highlanders and their coastal neighbours. If the biblical portrayal of the Philistines reflects seven-century realities, ${ }^{44}$ a distinctive Israelite ethnicity arose in reaction to Neo-Assyrian imperialism involving large-scale social, demographic and economic changes for people on both sides. Ethnic identification offers a way of maintaining continuity in the face of such fundamental changes ${ }^{45}$ Hence, it would be unsurprising to observe the advent of Assyrian influence provoking ethnic identity formation processes in parts of the southern Levant.$^{46}$ Moreover, similarities shared by the groups that seek to distinguish themselves are as crucial as their differences: ethnic formation phenomena are most likely to occur in situations in which the groups on either side of the boundary are, in significant number of respects, very similar... the confrontation of minor differences in the context of overall similarity poses a greater challenge than the broad strokes of total difference. $^{47}$

\footnotetext{
37 Coote 2006: 45.

38 Wolinski 2010.

39 Bloch-Smith 2003.

40 Gruen 2013 argues that the Romans were free of ethnic prejudice.

41 Brown 2014: 517.

42 Eriksen 2010: 17.

43 Lucy 2005: 101.

44 Finkelstein 2002.

45 Brown 2014: 518.

46 Crouch 2014: 98.

47 Crouch 2014: 95 quoting Harrison 1999; 2003.
} 
Besides greater mobility, contact and interchange generated by long distance trade, the large scale deportations initiated by the Neo-Assyrian Empire made homeland and common descent powerful categories. ${ }^{48}$

Stricto sensu ethnicity is a Hellenistic notion, at a time when ethnos became a tool of imperial rule. The rise of significant ethnic markers could nevertheless have started already with the cultural flux of the Neo-Assyrian era, hardly any earlier. As nativism is a reaction to internationalism, the aspiration of Neo-Assyrian rulers to 'turn into Assyrians' every group living within the confines of the empire gave rise to proto-ethnicities. ${ }^{49}$ Therefore, it is highly unlikely that pork consumption or pork avoidance was a significant marker of identity in the Levant before the seventh century BCE. ${ }^{50}$

\section{PORK COMPENSATING GRAZING GROUNDS SHRINKAGE IN THE IRON AGE II?}

Pig husbandry has been viewed as the strategic response to the lack of hinterland of the Philistine urban 'city-villages'. ${ }^{51}$ This notion is then applied to the Israelite lowland sites. In the Jezreel Valley, the demographic explosion of the Iron Age II combined with a slightly dryer climate supposedly led to a shift in meat production. Overgrazing forced farmers to reduce the size of flocks and compensate the loss of mutton with pork from sty-fed pigs. ${ }^{52}$ There are major problems here.

\section{DEMOGRAPHIC EXPLOSION AND GRAZING GROUNDS SHRINKAGE?}

The idea that the population explosion of the Iron Age II, significant as this explosion was compared to earlier demographic levels, impacted the availability of grazing grounds, is dubious. In the western Jezreel Valley, the increase of the number of sites is estimated from 46 to 66 with a total built-up surface from 57 to 72 hectares between the Iron Age I and the peak in the Iron Age II. The increase in the Samarian highland is more significant: from 80 sites in the Iron Age I to 240 sites in the Iron Age II. ${ }^{53}$ These figures remain modest compared to the size of the regions in question: $450 \mathrm{~km}^{2}$ for the western Jezreel Valley and $1,800 \mathrm{~km}^{2}$ for the Samarian region. ${ }^{54}$

These figures derive from the collection of surface sherds, sometimes from only a portion of sites when the rest was covered by thick vegetation or inhabited by Palestinians. Hence, site surface estimates are very approximative and even more so the population levels based on them since population density can vary enormously from site to site. ${ }^{55}$

\footnotetext{
48 Antonaccio 2010: 46.

49 Fales 2013.

50 Niesiołowski-Spanò 2015.

51 Shavit 2008: 158-159.

52 Sapir-Hen et al. 2013: 13.

53 Finkelstein et al. 2006: 760.

54 Finkelstein et al. 2006: 705.

55 Leibner 2014.
} 
For what they are worth, these figures can be compared with estimates of land use in prehistoric Europe. A typical 30-person settlement would have covered 4.5ha for houses, outbuildings and gardens. It would have needed 13.2ha of wheat and 57ha of woodland for fuel and timber. Its 40 heads of cattle and 40 heads of caprovids would have needed about 40 ha of pasture land plus $2.56 \mathrm{~km}^{2}$ of forest browse. ${ }^{56}$

The 72ha of built-up surface in Iron Age II western Jezreel Valley correspond to sixteen European prehistoric settlements $(16 \mathrm{x} 4.5 \mathrm{ha}=72 \mathrm{ha})$. In this case, at the population peak during the Iron Age II, the inhabitants of the western Jezreel Valley would have needed 211.2ha (13.2 x 16ha) of wheat and 912ha (57 x 16ha) of woodland for fuel and timber. Their livestock would have needed about 640ha (16 x 40ha) of pasture and $40.96 \mathrm{~km}^{2}$ $\left(16 \times 2.56 \mathrm{~km}^{2}\right)$ of forest browse, altogether $58.6 \mathrm{~km}^{2}\left(211.2 \mathrm{ha}+912 \mathrm{ha}+640 \mathrm{ha}+41 \mathrm{~km}^{2}\right)$. As the western Jezreel Valley covers $450 \mathrm{~km}^{2}$, its population could have been multiplied by a factor of eight before its carrying capacity would have been reached.

Obviously, prehistoric Europe is not the Iron Age Jezreel Valley. The bone repertoires in the Levant hold a much larger amount of caprovids and less bovines than Susan Gregg's estimate that count an equal number of heads of both types. Moreover, fuel requirements are likely to be lower in the Jezreel Valley than in Europe. Though all these figures are very approximate estimates, the comparison indicates that the notion of land shortage in the Iron Age II is suspect and can hardly explain the rise of pig bone ratios in the Jezreel Valley.

\section{PORK CONSUMPTION AND LOW ECONOMIC STATUS?}

A second issue concerns the most interesting result of the study: the sharp difference of the amount of pig bones between urban and rural 'Philistine' sites. The rural-urban dichotomy is problematic for Iron Age I Palestine, ${ }^{57}$ but for the present discussion it may be taken as valid. More problematic is the notion that larger numbers of pigs are correlated with lower economic status. ${ }^{58}$

The correlation between pig breeding and low social strata is based on the idea that the swine would not be a favored resource in complex, often centrally coordinated urban economies in the Ancient Near East. ${ }^{59}$ What evidence is there for such a claim?

A social stigma was indeed attached to pork consumption in Egypt in the sixteenth century BCE when pork was viewed as characteristic of a poor man's diet, but the amount of pig bones in the wealthy urban centres in Egypt and in the Levant counters the notion that a similar view existed in the Iron Age. ${ }^{60}$ Despite the claim that Egyptians considered pigs unclean (Herodotus II.47), Egyptians raised pigs and ate them. ${ }^{61}$ The sacrifice of pigs

\footnotetext{
56 Gregg 1988: 165-167.

57 Guillaume 2016.

58 Sapir-Hen et al. 2013: 11.

59 Zeder 1996: 308.

60 Redding 1991; Lobban 1998.

61 Clarysse, Thompson 2006: 208-217.
} 
is well attested in Egypt and the consumption of pork was only restricted for priests. ${ }^{62}$ In this case, the notion that larger numbers of pigs are correlated with lower economic status may be valid for Egypt.

In Mesopotamia, hemerologies deem the consumption of pork dangerous only at certain times: on 27 VII along with beef (Babylonian Almanac), alone on 28 VII (Offering Bread Hemerology), and together with leek, cress, beef and grilled meats in general. The Hemerology for Nazimaruttaš adds pork and dates on 5 VIII. The consumption of pork together with beef and grilled meats on 4 VII is deemed dangerous by the Original of Akkad. ${ }^{63}$ The concentration of the prohibition of pork, and often of beef as well, on month seven reflects the general view of the seventh month as unfavourable, though it is mostly its first seven days that are 'numinously evil'. ${ }^{64}$ The absence of pork on the menu of Aššurnașirpal's banquet $^{65}$ could find an explanation if the banquet occurred on the days when pork alone was deemed dangerous. In any case, pork consumption and abstinence in Mesopotamia is more a matter of calendar than of economic status.

In the Levant, the highest pig bone ratios in urban centres both on the coast (Iron Age I) and in the Jezreel Valley (Iron Age IIA-B) occur during prosperous times. ${ }^{66} \mathrm{High}$ pig bone ratios are also a reflection of urbanisation, an explanation that applies as much to Iron Age I coastal centres as to the Jezreel Valley in the Iron Age II. The difference in pig bone ratios reflects the difference between rural and urban conditions, urbanisation being as a rule more advanced in coastal lowlands than in the highland. As urban lowland settlements typically display higher material repertoires than rural highland settlements, pig bone ratios are highest in lowland urban settlements thanks to the higher economic status of lowland urbanites. Therefore, the correlation of high pig bone ratios with prosperous urban centres is hard to reconcile with the claim that larger numbers of pigs are correlated with lower economic status. ${ }^{67}$ To do so one would have to argue that elites resided in rural sites with low pig bone ratios, or that pig bones in urban sites were only recovered from quarters inhabited by the populace. The notion that elites avoided pork can hardly explain the rise of the pork taboo.

\section{STALLED PIGS IN CRAMPED ISRAELITE VALLEYS?}

To support the claim that pig husbandry was the solution to overpopulation and the subsequent shortage of grazing land in Israelite lowland sites, Lidar Sapir-Hen and others ${ }^{68}$ explain that pigs do not need to be driven to pasture when there is enough available food,

\footnotetext{
62 Volokhine 2014: 169-211; el-Huseny 2006.

63 Livingstone 2013: 264-265.

${ }^{64}$ Livingstone 2013: 276.

65 Grayson 1991: 175-176.

66 Sapir-Hen et al. 2013: 21.

${ }^{67}$ Sapir-Hen et al. 2013: 11.

68 Sapir-Hen et al. 2013: 2.
} 
such as vegetables and animal waste. ${ }^{69}$ Where on earth did such a surplus of vegetables and animal waste come from if the valleys were overpopulated and overgrazed to the point that flocks and herds had to be reduced?

As argued above, pig husbandry reflects favourable economic conditions and it is only in this sense that the greater availability of food surpluses in urban settlements made pig husbandry within urban settlements economically viable. Yet, for pigs to thrive on vegetables, Iron Age II farmers would have had to revert to intensive market gardening. As for the animal wastes, what could they be? Whey-milk from a thriving dairy industry comes to mind, but it is unlikely if grazing land for sheep and goats, never mind cows, was in short supply.

Only the concentration of refuse from proto-industrial operations (bakeries, silo bottoms, olive pressings) within urban centres would have made feeding stalled pigs economically viable. ${ }^{70}$ Yet, this remained marginal throughout the Iron Age as the number of pig bones is rarely above $10 \%$ of the total animal bone repertoire.

Pigs may indeed have been raised in sties centuries earlier at Tell el-Amarna, another royal capital towards which food surplus converged. ${ }^{71}$ The case of Amarna thus supports the notion that sty-bred pigs occurred only in certain central sites where pigs recycled urban refuses. Apart from these rare sites, pork could not replace mutton until the advent of modern agro-industrial operations. In the Iron Age, solving problems resulting from overpopulation with pork makes no sense whatsoever.

Apart from the stalled pigs in urban centres, most pigs across the world were raised in a free range manner. ${ }^{72}$ The advent of intensive piggeries in the twentieth century CE led to the termination of traditional methods, except in marginal areas. Modern pigs, except in luxury bio-farms, are now raised indoors, where they are fed a mixture of dairy and milling industry by-products (whey-milk, cereals and soy). As late as World War II, pigs in rural southern France were still being driven off in the morning beyond the cultivated belt around villages. Pigs spent the day as a group foraging in the woods for acorns, beechmasts, chestnuts, grubs, fruits, roots, mice, insects, snails, mushrooms, and worms. In the evening, a small amount of kitchen refuse was enough to entice the pigs to return to their respective owners' homes. The economic justification of breeding pigs was based on their ability to feed themselves in and beyond the settlements. ${ }^{73}$ Although he states that pigs can make shift in any sort of country wherever situated, ${ }^{74}$ Columella (7.9.6) adds that the most convenient feeding-grounds for pigs are woods covered with various kinds of oaks, nut and wild fruit trees. The same was true in Medieval England where it was designated

\footnotetext{
69 Sapir-Hen et al. 2013: 2.

70 Hadjikoumis 2012.

71 Shaw 1986.

72 Rognon 2006.

${ }^{73}$ Halstead, Isaakidou 2011: 164.

${ }^{74}$ Columella, Agriculture 1968: 293.
} 
as pannage. ${ }^{75}$ This was probably true in third millennium BCE Mesopotamia where pig bone ratios seem to follow the climatic variations: they rise when greater humidity favours forestation and decline when dryer conditions led to deforestation. ${ }^{76}$

Free range pig husbandry survives in Sardinia where breeders report that they might not see their pigs for an entire month when there is enough food in the woods. The animals usually remain within a ten kilometer radius of the farm and eventually come back to the sty. The exception is uncastrated boars that may sometimes be lost. ${ }^{77}$ In Corsica, a form of transhumance is still practised. The cochons coureurs are taken to the highlands in the summer where they are left to feed themselves.

With or without transhumance, open range breeding involves far less human supervision than is the case with sheep and goats. Pigs only have predators when the human demography is small enough to enable the development of large predators such as lions and bears. ${ }^{78}$ Otherwise, only newborn piglets are at risk from foxes and large birds of prey. ${ }^{79}$ Ancient pigs constantly navigated between the domestic and wild spheres, a fact that blurs the line between breeding and hunting: Zooarchaeologists may sometimes be too keen to make a clear distinction between the management of domestic and wild resources. This hardly seems to be applicable to all areas and situations. In Sardinia and Corsica not only is there a biological continuum between the two Sus forms, but also husbandry practices are geared towards a combined management of wild boar and domestic pigs, whose interbreeding is in some cases regarded as an opportunity, but more often as a nuisance... Our study of modern Sardinian and Corsican pig husbandry indicates that the emphasis in our explanations must be on management rather than biological status, as the second is by and large the product of the first. ${ }^{80}$

The emphasis on management rather than on biological status reduces the relevance of DNA studies for the understanding of the biblical pork taboo as free range pig husbandry affords plenty of opportunity for the occasional domesticated pigs to go feral and for domestic sows to be fertilised by wild boars, themselves likely descendants of domestic pigs that went feral. ${ }^{81}$ The hybridisation between wild and domestic pigs goes both ways to the point that genetically and phenotypically they are hard to distinguish. Hybridisation can even be a conscious breeding strategy to save on the expenses of keeping boars and the inherent danger mature uncastrated boars represent to humans. ${ }^{82}$ Every male piglet can be culled or castrated when wild boars can be relied upon to inseminate domestic sows. The suidae, then, represent a particular case where the distance between domestic and wild strands is very small. This unique phenomenon is reflected in Babylonian lexical

\footnotetext{
75 Albarella 2006.

76 Piątkowska-Małecka, Smogorzewska 2010: 36-37.

77 Albarella, Manconi, Trentacoste 2011: 155.

78 Bear bones are reported in Iron Age contexts from Jaffa, Tell Qiri and Tell Hadid (Fantalkin 2005: 17).

79 Albarella, Manconi, Trentacoste 2011: 156.

80 Albarella et al. 2007: 305.

81 Albarella, Manconi, Trentacoste 2011: 146.

82 Hadjikoumis 2012: 360.
} 
texts where lexicographers found it difficult to classify pigs and listed different categories of pigs between domesticated and wild animals. ${ }^{83}$

The usefulness of the biometrical differences used to distinguish between wild and domesticated suidae in zooarchaeological studies is equally doubtful. This criterion is heavily dependent on comparison with modern breeds and its application can only provide tentative distinctions. ${ }^{84}$

Mortality profiles and the dominance of bones of juveniles bearing butchering marks, other criteria used to determine domestic status, are even more problematic in light of the small samples currently available. Thanks to their smaller size, younger wild pigs were more likely to be caught by hunters and brought back home than larger adult specimen that are far more dangerous to hunt and heavier to carry back to the settlement. The criteria of size and mortality profile thus interfere as much as they complement one another ${ }^{85}$ If pig bones with butchering marks reveal pork consumption, they do not reveal economic specialization. $10 \%$ of pig bones in any bone assemblage can hardly be taken as the indication of economic specialisation in pig husbandry.

The slightly higher ratios of pig bones in urban centres than in rural sites results from the greater availability of food surpluses, grain and olive pressings. Within the walls of Bronze Age Ugarit one olive oil workshop is counted to every ten houses. ${ }^{86}$ Hence, in the urban economies of the ancient Levant swine would recycle the refuse produced by oil presses and the remains from the large grain storage facilities that characterise the economic function of urban centres. Far from holding the same place as humans on the food chain, pigs made the most of what humans did not eat: urban refuse and products of the wild.

Nevertheless, urban stalled pigs as much as free range husbandry remained marginal even in the Roman world where the leaner, long-legged, wild-boar-like breed remained most prevalent, for the simple reason that it was better adapted for foraging in the woods and for herding on the hoof to markets. ${ }^{87}$ In the Levant and in Greece, cheap cereal feed only became available in the second part of the twentieth century. ${ }^{88}$ This belies the notion that enough food was available in ancient Levantine villages to feed stalled pigs. Apart from Roman bakers, olive oil pressers from Ekron (even though the percentage of pig bones in the recovered assemblage of the Iron Age II is significantly smaller than that of the Iron Age I) and the managers of the Megiddo silo, ancient Levantine farmers relied on the ability of pigs to feed themselves in the wild, a view which finds some support from the Hebrew Bible.

\footnotetext{
${ }^{83}$ Veldhuis 2006.

${ }^{84}$ Albarella et al. 2006; Hesse, Wapnish 2002: 469; Vila 2004: 95.

${ }^{85}$ Albarella 2002.

${ }^{86}$ Callot 1993.

${ }^{87}$ MacKinnon 2001: 664.

${ }^{88}$ Halstead, Isaakidou 2011: 165.
} 


\section{Free Range Pig Husbandry in the Hebrew Bible}

The irrelevance of the wild/domestic distinction when discussing pigs is reflected in biblical Hebrew and other Semitic vocabulary, which use the same word for domestic pigs and wild boars. ${ }^{89}$ The lack of differentiation in the vocabulary reflects the lack of phenotypical differences in ancient domesticated and wild pigs that shared similar coat colours and other morphological characteristics. ${ }^{90}$ Hence, Ps 80:14 mentions a pig of the forest (חזיר מיער) to designate a wild pig. A metaphor in Prov 11:22 confirms the existence of free range pigs in ancient Israel: נזם זהב באף חזיר אשה יפה וסרת טעם, A golden ring in a pig's nose (is) a beautiful woman without discernment. Hence, free range pig husbandry was common knowledge in ancient Israel and Judah. This in itself does not prove that Israelites and Judeans ate pork, but it indicates some familiarity with domestic pigs and how to deal with them.

\section{ISRAELITE REFUGEES IN JUDAH AFTER 720 всE?}

To bridge the gap between the pork-eating Israelites of the Iron Age II and the completion of the Torah in the Persian period, a flood of Israelite refugees into Judah around $720 \mathrm{BCE}$ is postulated. This flood supposedly explains how the pork taboo reached Jerusalem and became entrenched there to the point that it was recorded in the Torah. As this flood has been repeatedly refuted there is no need to repeat the arguments that militate against it. ${ }^{91}$ It is enough to doubt the link between Hezekiah or Josiah's desire to rule from Dan to Beer-sheba and even more the 'continuing concern regarding pigs' in Judah after the withdrawal of the Assyrians from the Levant. ${ }^{92}$

Tellingly, the argument of a specialisation on pig husbandry evoked as a strategy in crowded northern Israel is not applied to Judah when it was supposedly flooded by Israelite refugees. If the demographic explosion in Iron Age II Israel led to shift meat production towards pork, nothing of the sort happened in Judah: Judah too features dramatic population growth in the Iron Age IIB; still, in the Iron Age IIB, as in earlier periods, the population of Judah was much smaller than that of Israel and hence there could have been enough open-spaces, especially in the Sheffelah. ${ }^{93}$

If pork abstinence indeed existed as an Israelite and Judean cultural trait as far back as the Iron Age I and that it was only under economic duress that Israelites started eating pork in order to survive in their overcrowded valleys, why, once settled in less populated Judah, did the Israelite refugees continue raising pigs when more space was available, despite their flooding of Judah?

The scenario needs the Israelites to remain hooked on pork, both those Israelites who flooded Judah and those who remained in depopulated Israel after the collapse of the

\footnotetext{
${ }^{89}$ HALOT 1:302; Viré 2010; Huehnergard 1987: 84-85; CAD Hु, 266.

90 Meiri et al. 2013: 4.

91 See Na'aman 2007; 2014.

92 Sapir-Hen et al. 2013: 13.

93 Sapir-Hen et al. 2013: 13.
} 
Northern Kingdom. Otherwise, their pork eating habits could not become an issue for their Judahite hosts and for King Josiah who supposedly sought to rule over the territories of the Assyrian province of Samaria. Not only the Israelites did not revert to the pork abstinence of their Iron Age I ancestors in the days of Josiah, but they remained hooked on pork for centuries till the Achaemenid era when their pork consumption habits remained acute enough in the eyes of Judahite writers of the Torah who wished to impose the biblical pork taboo on the entire population.

In fact, there is no indication for any Judean concern regarding pork consumption habits in northern Israelite territories. According to the biblical text, Josiah destroyed cultic paraphernalia at Bethel, desecrated tombs and burnt human bones on the altar there (2 Kgs 23:15-16). Hence, the link between Judahite concerns regarding Israelite pigs after the Assyrian withdrawal and the biblical taboo is strained. What remains is the parallelism between pork consumption in urban centres, whether Philistine or Israelite. The significance of this fact surfaces all-the-more clearly once Melinda Zeder's axiom is overturned and that pork consumption is viewed as a mark of higher economic conditions in urban centres. The straight-forward interpretation of the data (see Tab. 1 above) is that pig bone ratios rise with economic conditions until the second part of the first millennium BCE. The correlation applies to thriving urban sites both in Philistia and in Israel.

\section{CONCLUSION}

As the Torah was considered authoritative in the Ptolemaic era, the biblical taboo was formulated in the Persian era at the latest. The circumstances in which the biblical taboo emerged have to be reconstructed from the ecological and economic factors that prevailed then.

A first notion to reject is that since pigs love woodland there would be no pigs or wild boars in the deforested mountains of Palestine. ${ }^{94}$ In fact, wild pigs and gazelles are identified as the two wild species that are the least affected by deforestation..$^{95}$ The increase of pig bones detected in lowland sites considered under Israelite rule in the Iron Age II (Yoqneam, Rehov and Hazor) shows that the relative deforestation following the population explosion of the Iron Age II in no way eradicated pigs. The consumption of pork increased, obtained either from free range pigs, from hunted wild boars or both. The extension of ploughed fields and olive groves at the expense of oaks and caroub trees was not significant enough to reduce the amount of acorns and other pig food to the point that free range pig husbandry became uneconomical. ${ }^{96}$ What about the Persian era?

The reforestation that followed the depopulation of Yehud after the Babylonian destructions seriously reduced the number of pork eaters while increasing the amount of pig food available in the forest. In depopulated Yehud wild pigs, gazelles and wild birds were an abundant source of meat. Plentiful game reduced the incentive to raise pigs. The presence

\footnotetext{
94 Lemche 2010: 100.

95 Tsahar et al. 2009.

96 Liphschitz 2007: 48-49; 2008.
} 
of bears, leopards and other such predators in the woods and thickets between settlements would have further reduced the incentive to raise free range pigs.

The grand reconstruction proposed by our Tel Aviv colleagues hardly advances our understanding of the rise of the biblical taboo. The Hellenistic melting-pot did spur the need for 'we'-and-'they' boundaries with close neighbours. Pushing this need as far back as the Iron Age I has no archaeological or historical support whatsoever. Therefore, Brian Hesse and Paula Wapnish's reluctance to accept this scenario should be reaffirmed until more convincing arguments are presented.

\section{References}

Albarella, U. 2002: 'Size matters': how and why biometry is still important in zooarchaeology, [in:] Dobney, K., O’Connor, T. (Eds), Bones and the Man: Studies in Honour of Don Brothwell, Oxford, 51-62

Albarella, U. 2006: Pig Husbandry and Pork Consumption in Medieval England, [in:] Woolgar, C.M., Serjeantson, D., Waldron, T. (Eds), Food in Medieval England: Diet and Nutrition, Oxford, 72-87

Albarella, U., Manconi, F., Rowley-Conwy, P., Vigne, J.-D. 2006: Pigs of Corsica and Sardinia: a biometrical re-evaluation of their status and history, [in:] Tecchiati, U., Sala, B. (Eds), Archaeozoological Studies in Honour of Alfredo Riedel, Bolzano, 258-302

Albarella, U., Manconi, F., Trentacoste, A. 2011: A week on the plateau: Pig husbandry, mobility and resource exploitation in central Sardinia, [in:] Albarella, U., Trentacoste, A. (Eds), Ethnozooarchaeology. The Present and Past of Human-animal Relationships, Oxford, 143-159

Albarella, U., Manconi, F., Vigne, J.-D., Rowley-Conwy, P. 2007: The Ethnoarchaeology of pig husbandry in Sardinia and Corsica, [in:] Albarella, U., Dobney, K., Ervynck, A., Rowley-Conwy, P. (Eds), Pigs and Humans: 10,000 years of Interaction, Oxford, 285-307

Antonaccio, C.M. 2010: (Re)Defining Ethnicity: Culture, Material Culture and Identity, [in:] Hales, S., Hodos, T. (Eds), Material Culture and Social Identities in the Ancient World, Cambridge, 32-53

Bloch-Smith, E. 2003: Israelite Ethnicity in Iron I: Archaeology Preserves what is Remembered and what is Forgotten in Israel's History, JBL 122, 401-425

Brown, B.A. 2014: Culture on Display: Representations of Ethnicity in the Art of the Late Assyrian State, [in:] Brown, B.A., Feldman, M.H. (Eds), Critical Approaches to Ancient Near Eastern Art, Berlin, 515-542

Callot, O. 1993: Les huileries et l'huile au Bronze récent : quelques exemples syriens etchypriotes, [in:] Amouretti, M.-C., Brun, J.-P. (Eds), La production du vin et de l'huile en Méditerranée, BCH Supp. XXVI, Paris, 55-64

Clarysse, W., Thompson, D.-J. 2006: Counting the People in Hellenistic Egypt. Volume 2: Historical Studies, Cambridge 
Columella, Agriculture 1968: Columella, On Agriculture, vol. II, transl. E.S. Forster, E.H. Heffner, LCL 407, Cambridge, Mass.-London 1968

Coote, R.B. 2006: Tribalism: Social Organization in the Biblical Israels, [in:] Esler, P.F. (Ed.), Ancient Israel: The Old Testament in Its Social Context, Minneapolis, 35-49 Crouch, C.L. 2014: The Making of Israel: Cultural Diversity in the Southern Levant and the Formation of Ethnic Identity in Deuteronomy, VetTest-Suppl. 162, Leiden

Diebner, P., Robkin, E.E. 1978: Ecology, Evolution and the Search for Cultural Origins: The Question of Islamic Pig Prohibition, CurrAnthr 19, 493-540

Douglas, M. 1975: Deciphering a Meal, [in:] Douglas, M., Implicit Meanings: Essays in Anthropology, London, 249-275

el-Huseny, A. el-H.M. 2006: Die inkonsequente Tabuisierung von Sus scrofa Linnaeus, 1758 im Alten Ägypten: seine ökonomische und religiöse Bedeutung, Berlin

Eriksen, T.H. 2010: Ethnicity and Nationalism: Anthropological Perspectives, London Fales, F.M. 2013: Ethnicity in the Assyrian Empire: A View from the Nisbe, (I): Foreigners and 'Special' Inner Communities, [in:] Vanderhooft, D.S., Winitzer, A. (Eds), Literature as Politics, Politics as Literature. Essays on the Ancient Near East in Honor of Peter Machinist, Winona Lake, 47-74

Fantalkin, A. 2005: A Group of Iron Age Wineries from Ancient Jaffa (Joppa), [in:] Salvage Excavations Reports 2, Tel Aviv, 3-26

Faust, A. 2007: Israel's Ethnogenesis: Settlement, Interaction, Expansion and Resistance, London

Faust, A. 2012: The Archaeology of Israelite Society in Iron Age II, Winona Lake

Faust, A. Bunimovitz, S. 2003: The Four-Room House: Embodying Israelite Society, NEA (ASOR) 66, 22-31

Faust, A., Lev-Tov, J. 2011: Constitution of Philistine Identity. Ethnic Dynamics in Twelfth to Tenth Century Philistia, OJA 30/1, 13-31

Finkelstein, I. 1988: Archaeology of the Israelite Settlement, Jerusalem

Finkelstein, I. 1997: Pots and People Revisited: Ethnic Boundaries in the Iron Age I, [in:] Silberman, N.A., Small, D. (Eds), The Archaeology of Israel: Constructing the Past, Interpreting the Present, JSOT-Suppl. 237, Sheffield, 216-237

Finkelstein, I. 2002: The Philistines in the Bible: A Late-Monarchic Perspective, JSOT 27/2, 131-167

Finkelstein, I. 2007: The Two Kingdoms: Israel and Judah, [in:] Schmidt, B. (Ed.), The Quest for the Historical Israel, Atlanta, 147-157

Finkelstein, I., Halpern, B., Lehmann, G., Niemann, H.M. 2006: The Megiddo Hinterland Project, [in:] Finkelstein, I., Ussishkin, D., Halpern, B. (Eds), Megiddo IV: the 1998-2002 Seasons, Institute of Archaeology of Tel Aviv University, Monograph Series 24, Tel Aviv, 705-776

Foster, B.R., Salgues, E. 2006: Everything except the Squeal. Pigs in Early Mesopotamia, [in:] Lion, B., Michel, C. (Eds), De la domestication au tabou : le cas des suidés dans le Proche-Orient ancien, Travaux de la Maison René-Ginouvès 1, Paris, 283-291 
Grayson, A.K. 1991: Assyrian Rulers of the Early First Millennium BC I, Royal Inscriptions of Mesopotamia 1, Toronto

Gregg, S. 1988: Foragers and Farmers: Population Interaction and Agricultural Expansion in Prehistoric Europe, Prehistoric Archeology and Ecology 275, Chicago

Gruen, E. 2013: Did the Romans have an Ethnic Identity?, [in:] Burton, P.J. (Ed.), Culture, Identity and Politics in the Ancient Mediterranean World. Papers from a Conference in Honour of Erich Gruen, Antichthon 47, 1-17

Guillaume, P. 2016: Poor by Necessity or by Choice? Ancient Israelite Egalitarianism, [in:] Grabbe, L.L. (Ed.), The Land of Canaan in the Late Bronze Age, Library of Hebrew Bible/Old Testament Studies 636, London-New York, 102-111

Hadjikoumis, A. 2012: Traditional Pig Herding Practices in Southwest Iberia: Questions of Scale and Zooarchaeological Implications, JAA 31, 353-364

Halstead, P., Isaakidou, V. 2011: A Pig Fed by Hand is Worth Two in the Bush: Ethnoarchaeology of Pig Husbandry in Greece and its Archaeological Implications, [in:] Albarella, U., Trentacoste, A. (Eds), Ethnozooarchaeology: the Present and Past of Human-Animal Relationships, Oxford, 160-174

Hamilton-Dyer, S. 2001: The Faunal Remains, [in:] Maxfield, V.A., Peacock, D.P.S. (Eds), Mons Claudianus 1987-1993: Survey and Excavation, vol. 2: The Excavations, Cairo, 249-301

Harris, M. 1977: Cannibales et monarques. Essai sur 1'origine des cultures, Paris

Harrison, S. 1999: Identity as a Scarce Resource, Social Anthropology 7/3, 239-251

Harrison, S. 2003: Cultural Difference as Denied Resemblance: Reconsidering Nationalism and Ethnicity, CSSH 45/2, 343-361

Henninger, J. 1982: Nouveaux débats sur l'interdiction du porc dans l'Islam, [in:] Digard, J.P. (Ed.), Le cuisinier et le philosophe. Hommage à Maxime Rodinson, Genève, 29-40

Hesse, B., Fulton, D.N., Wapnish, P. 2011: Animal Remains, [in:] Stager, L.E., Master, D.M., Schloen, J.D. (Eds), Ashkelon 3: the Seventh Century B.C., Winona Lake, 615-644

Hesse, B., Wapnish, P. 2002: An Archaeozoological Perspective on the Cultural Use of Mammals in the Levant, [in:] Collins, B.J. (Ed.), A History of the Animal World in the Ancient Near East, Handbook of Oriental Studies. Section 1. The Near and Middle East 64, Leiden-Boston, 457-491

Hocine Benkheira, M. 2006: Quelques interprétations anthropologiques du tabou du porc en Islâm, [in:] Lion, B., Michel, C. (Eds), De la domestication au tabou : le cas des suidés dans le Proche-Orient ancien, Travaux de la Maison René-Ginouvès 1, Paris, 233-244

Huehnergard, J. 1987: Ugaritic Vocabulary in Syllabic Transcription, Atlanta Joffe, A.H. 1999: Ethnicity in the Iron I Southern Levant: Marginal Notes, Akkadica 112, 27-33

Köhler-Rollefson, I. 1995: The Animal Bones, [in:] Bennett, C.-M., Bienkowski, P. (Eds), Excavations at Tawilan in Southern Jordan, British Academy Monographs in Archaeology 8, Oxford, 97-100 
Leibner, U. 2014: Determining the settlement history of Hellenistic, Roman, and Byzantine Sites in the Galilee, Israel: Comparing surface, subsurface, and stratified artifact assemblages, JFA 39/4, 387-400; DOI: 10.1179/0093469014Z.00000000088

Lemche, N.P. 2010: Avraham Faust, Israel's Ethnogenesis, and Social Anthropology, [in:]

Pfoh, E. (Ed.), Anthropology and the Bible: Cultural Perspectives, Piscataway, 93-104 Lev-Tov, J.S.E. 2012: A Preliminary Report on the Late Bronze and Iron Age Faunal Assemblage from Tell es-Safi/Gath, [in:] Maeir, A.M. (Ed.), Tell es-Safi/Gath I:

The 1996-2005 Seasons, ÄAT 69, Wiesbaden, 589-612

Liphschitz, N. 2007: Timber in Ancient Israel: Dendroarchaeology and Dendrochronology, Monograph Series 26, Tel Aviv

Liphschitz, N. 2008: Reconstruction of the Arboreal Vegetation of the Judean and Samarian Mountains During Antiquity as Evident from Archaeological Wood Remains, [in:] Bar, S. (Ed.), In the Hill-Country, and in the Shephelah, and in the Arabah (Joshua 12, 8): Studies and Researches Presented to Adam Zertal in the Thirtieth Anniversary of the Manasseh Hill-Country Survey, Jerusalem, 48-55

Livingstone, A. 2013: Hemerologies of Assyrian and Babylonian Scholars, Cornell University studies in Assyriology and Sumerology 25, Bethesda, MD

Lobban, R.A. 1998: Pigs in Ancient Egypt, [in:] Nelson, S.M. (Ed.), Ancestors for the Pigs: Pigs in Prehistory, Philadelphia, 137-148

Lucy, S. 2005: Ethnic and Cultural Identities, [in:] Díaz-Andreu, M. et al., The Archaeology of Identity: Approaches to gender, age, status, ethnicity and religion, London, 86-109 MacKinnon, M. 2001: High on the Hog: Linking Zooarchaeological, Literary, and Artistic Data for Pig Breeds in Roman Italy, AJA 105, 649-673

Meiri, M., Huchon, D., Bar-Oz, G., Boaretto, E., Kolska Horwitz, L., Maeir, A.M., SapirHen, L., Larson, G., Weiner, S., Finkelstein, I. 2013: Ancient DNA and Population Turnover in Southern Levantine: Pigs-Signature of the Sea Peoples Migration?, Scientific Reports 3035; DOI: 10.1038/srep03035

Mendelssohn, H., Yom-Tov, Y.A. 1999: Report of Birds and Mammals which have Increased their Distribution and Abundance in Israel due to Human Activity, Israel Journal of Zoology 45/1, 35-47

Na'aman, N. 2007: When and How did Jerusalem Become a Great City? The Rise of Jerusalem as Judah's Premier City in the Eighth-Seventh Centuries B.C.E., BASOR $347,21-56$

Na'aman, N. 2013: The Kingdom of Judah in the $9^{\text {th }}$ century bce: Text Analysis versus Archaeological Research, Tel Aviv 40, 247-276

Na'aman, N. 2014: Dismissing the Myth of a Flood of Israelite Refugees in the Late Eighth Century BCE, ZATW 126/1, 1-14

Niesiołowski-Spanò, Ł. 2013: The Philistines in Jerusalem? The Use of Archaeological Data as the Ethnic Marker: the Case of the Philistines, Other 'Sea Peoples', and Judah, [in:] Bombardieri, L. et al. (Eds), SOMA 2012. Identity and Connectivity: Proceedings of the 16th Symposium on Mediterranean Archaeology, Florence, Italy, 1-3 March 2012, vol. I, BAR-IS 2581, Oxford, 89-96 
Niesiołowski-Spanò, Ł. 2014: The Philistines as Intermediaries between the Aegean and the Near East, [in:] Thompson, T.L., Wajdenbaum, P. (Eds), The Bible and Hellenism: Greek Influence on Jewish and Early Christian Literature, Sheffield, 89-101

Niesiołowski-Spanò, Ł. 2015: Food or Drink? Pork or Wine? The Philistines and Their 'Ethnic' Markers, Scandinavian Journal of the Old Testament 29, 110-116

Nowak, R.M. 1999: Walker's Mammals of the World II, Baltimore, MD

Piątkowska-Małecka, J., Smogorzewska, A. 2010: Animal economy at Tell Arbid, northeast Syria, in the third millennium BC, BNE 4, 25-43

Poplin, F. 2006: Conclusion anthropozoologique. Le cochon, perle d'Orient : un tabou né de la domestication laitière, [in:] Lion, B., Michel, C. (Eds), De la domestication au tabou : le cas des suidés dans le Proche-Orient ancien, Travaux de la Maison René-Ginouvès 1, Paris, 325-331

Redding, R.W. 1991: The Role of the Pig in the Subsistence System of Ancient Egypt: A Parable on the Potential of Faunal Data, [in:] Crabtree, P.J., Ryan, K. (Eds), Animal Use and Culture Change, Philadelphia, 21-30

Rognon, X. 2006: Le porc domestique : biologie, zootechnie, diversité, [in:] Lion, B., Michel, C. (Eds), De la domestication au tabou : le cas des suidés dans le ProcheOrient ancien, Travaux de la Maison René-Ginouvès 1, Paris, 3-14

Ruane, N.J. 2015: Pigs, Purity, and Patrilineality: The Multiparity of Swine and Its Problems for Biblical Ritual and Gender Construction, JBL 134/3, 489-504

Sade, M. 1988: Domestic Mammals in the Iron Age Economy of the Northern Negev, unpublished MA thesis, Tel Aviv University, Tel Aviv

Sapir-Hen, L., Bar-Oz, G., Gadot, Y., Finkelstein, I. 2013: Pig Husbandry in Iron Age Israel and Judah. New Insights Regarding the Origin of the 'Taboo', ZDPV 129/1, $1-20$

Sapir-Hen, L., Meiri, M., Finkelstein, I. 2015: Iron Age Pigs: New Evidence of their Origin and Role in Forming Identity Boundaries, Radiocarbon 57, 307-315

Sasson, A. 2010: Animal Husbandry in Ancient Israel: a zooarchaeological perspective on livestock exploitation, herd management and economic strategies, London

Sasson, A., Greenfield, H.J. 2014: The Second Revolution of Secondary Products: Do Mortality Profiles Reflect Herd Management or Specialized Production?, [in:] Greenfield, H.J. (Ed.), Animal Secondary Products: Archaeological Perspectives on Domestic Animal Exploitation in the Neolithic and Bronze Age, Oxford, 206-218

Shavit, A. 2008: Settlement Patterns of Philistine City-States, [in:] Fantalkin, A., YasurLandau, A. (Eds), Bene Israel, Studies in the Archaeology of Israel and the Levant during the Bronze and Iron Ages in Honour of Israel Finkelstein, Culture and History of the Ancient Near East 31, Leiden, 135-164

Shaw, I. 1986: Report on the 1983 Excavations. The Animal Pens (Building 400), [in:] Kemp, B. (Ed.), Amarna Reports I, EES Occasional Publications 1, London, 40-59

Sherratt, A. 1981: Plough and Pastoralism: Aspects of the Secondary Products Revolution, [in:] Hodder, I., Isaac, G., Hammond, N. (Eds), Pattern of the Past: Studies in Honour of David Clarke, Cambridge, 261-305 
Stager, L.E. 1995: The Impact of the Sea Peoples in Canaan (1185-1050 BCE), [in:] Levy, T.E. (Ed.), The Archaeology of Society in the Holy Land, London, 332-348

Tsahar, E., Izhaki, I., Lev-Yadun, S., Bar-Oz, G. 2009: Distribution and Extinction of Ungulates during the Holocene of the Southern Levant, PLoS ONE 4(4): e5316; DOI: 10.1371 journal.pone. 0005316

Veldhuis, N. 2006: How to Classify Pigs: Old Babylonian and Middle Babylonian Lexical Texts, [in:] Lion, B., Michel, C. (Eds), De la domestication au tabou : le cas des suidés dans le Proche-Orient ancien, Travaux de la Maison René-Ginouvès 1, Paris, 25-29

Vila, E. 2004: The Fauna of Early Bronze Sidon, Archaeology and History in Lebanon $19,92-105$

Viré, F. 2010: Khinzīr, [in:] EncIsl; DOI: 10.1163/9789004206106_eifo_SIM_4289 (accessed July 8, 2018)

Volokhine, Y. 2014: Le porc en Egypte ancienne : mythes et histoire à l'origine des interdits alimentaires, Liège

Wilson, K.A. 2005: The Campaign of Pharaoh Shoshenq I into Palestine, FAT 2/9, Tübingen

Wolinski, P. 2010: Will the Real Philistine Please Stand Up? A Case Study of Ethnic Identification in the Early Iron Age Southern Levant, [in:] Matthiae, P. et al. (Eds), Proceedings of the Sixth International Congress of the Archaeology of the Ancient Near East 5 May - 10 May 2008, Sapienza, Università di Roma, vol. 1, Wiesbaden, 591-601

Zeder, M.A. 1996: The Role of Pigs in Near Eastern Subsistence: a view from the southern Levant, [in:] Seger, J.D. (Ed.), Retrieving the Past: Essays on archaeological Research and in honor of Gus W. Van Beek, Winona Lake, 297-312 


\section{ÉTUDES et TRAVAUX XXXI / 2018}

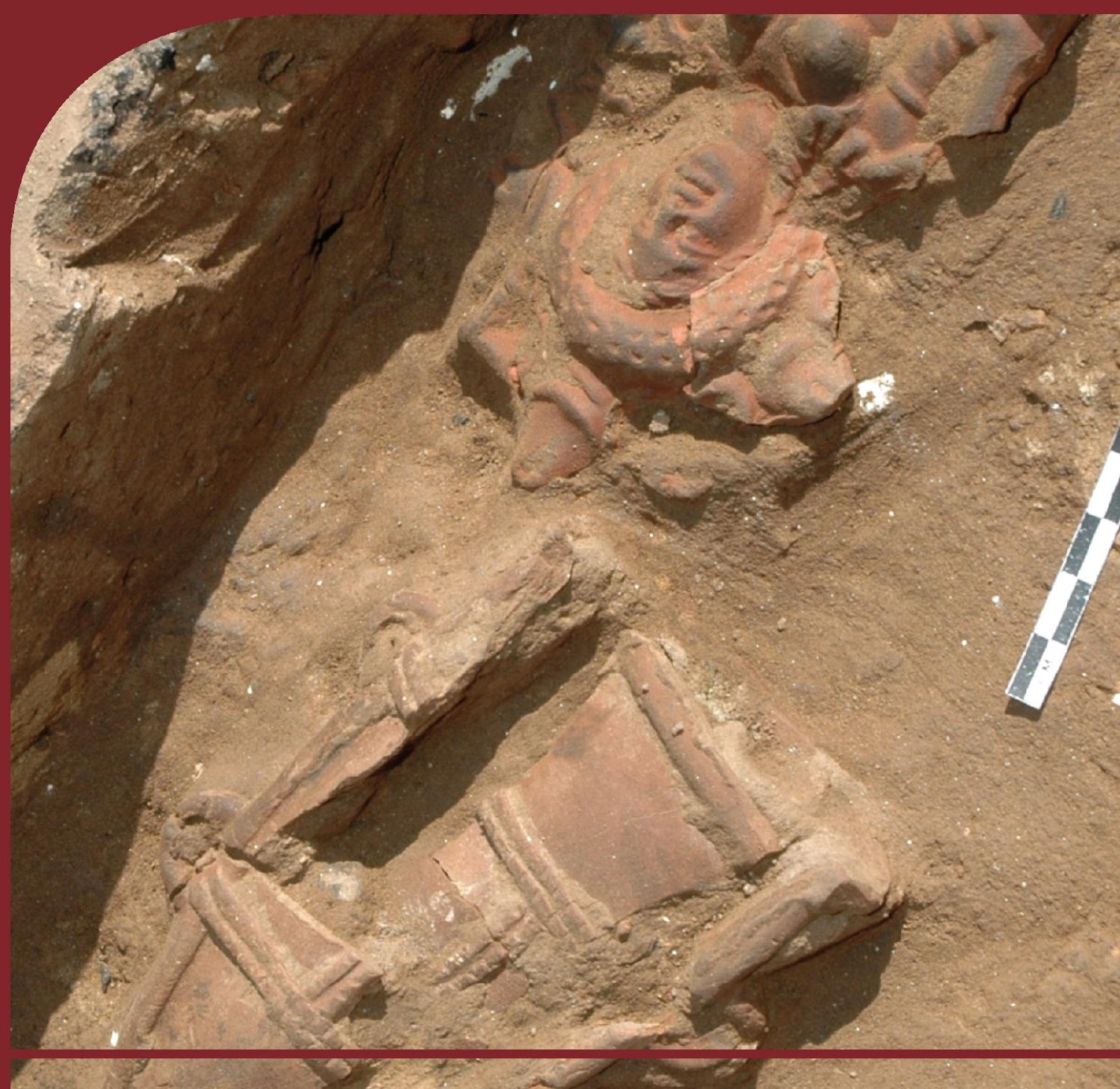

Institut des Cultures iyréditerranéennes et Oilentales FORIKSiO - de PAcadémie Polonaise des Sciences DS PA 


\section{COMITÉ DE RÉDACTION SCIENTIFIQUE}

Maciej Makowski - rédacteur en chef

Jadwiga Iwaszczuk - rédacteur

Mariusz Drzewiecki - sécretaire de la rédaction

Karol Myśliwiec - rédacteur thématique du volume

CONSEIL SCIENTIFIQUE DU JOURNAL

M. Kobusiewicz (IAE PAS, Warszawa), E. Laskowska-Kusztal (IMOC PAS, Warszawa)

D. Michaelides (University of Cyprus, Nicosia)

J.Ch. Moretti (IRAA-MOM, Université de Lyon 2/CNRS)

D. Raue (Ägyptisches Museum der Universität Leipzig), P. Reynolds (ICREA, España)

D. Welsby (British Museum, London)

\section{COMITÉ SCIENTIFIQUE DE LECTURE}

H.D. Baker (University of Toronto), P. Ballet (ArScAn-ESPRI, Université Paris Nanterre),

N. Beaux Grimal (IFAO, Cair/Collège de France, Paris), A. Dodson (University of Bristol),

L. Gabolde (CNRS), C. Gobeil (Egypt Exploration Society, London),

J. Holaubek (Institut für Ägyptologie, Wien), S. Ikram (American University in Cairo),

K. Innemée (Universiteit Leiden), Ch. Leitz (Universität Tübingen),

A. Loprieno-Gnirs (Universität Basel), Ch.E. Loeben (Museen für Kulturgeschichte, Hannover),

S. Ortisi (Universität München), A. Peignard-Giros (HiSoMA-MOM, Université de Lyon 2/CNRS),

E. Rova (Università Ca' Foscari Venezia), A. Sasson (San Diego Natural History Museum),

G. Schreiber (Eötvös Loránd University, Budapest), E. Teeter (University of Chicago),

Y. Tristant (Macquarie University, Sydney), V. Vaelske (independent researcher),

V.W.J. van Gerven Oei (independent researcher), H. Vymazalová (Charles University, Prague),

K. Winther-Jacobsen (Danish Institute at Athens),

J.A. Ostrowski, E. Papuci-Władyka, J. Śliwa (IA JU, Kraków),

R. Czerner (WUST, Wrocław), A. Ćwiek (IA AMU, Poznań),

K. Domżalski (IAE PAS, Warszawa), M. Pinker (FOS UW, Warszawa),

Ł. Niesiołowski-Spanò (IH UW, Warszawa), M. Gawlikowski (PCMA UW, Warszawa), K.O. Kuraszkiewicz (DE FOS UW, Warszawa), M. Barwik, P. Dyczek, W. Godlewski,

S. Rzepka, J. Żelazowski, A. Niwiński (IA UW, Warszawa)

\section{RÉDACTION TECHNIQUE}

Maciej Makowski, Jadwiga Iwaszczuk

CORRECTION LINGUISTIQUE

Jo Harper 
ÉTUDES et TRAVAUX

XXXI 
INSTYTUT KULTUR ŚRÓDZIEMNOMORSKICH I ORIENTALNYCH POLSKIEJ AKADEMII NAUK

\title{
STUDIA i PRACE
}

XXXI

\author{
gO IKŚiO \\ ESA PAN \\ WARSZAWA \\ 2018
}


INSTITUT DES CULTURES MÉDITERRANÉENNES ET ORIENTALES DE L'ACADÉMIE POLONAISE DES SCIENCES

\section{ÉTUDES et TRAVAUX}

XXXI

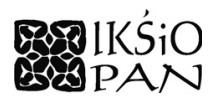

VARSOVIE

2018 
Publication scientifique financée dans le cadre du programme du Ministre de la Science et de l'Éducation Supérieure « Programme National de Développement de l'Humanistique » pour les années 2016-2021 (projet $n^{\circ} 3 \mathrm{bH} 15009983$ )

\title{
Harodowy PROGRAM ROZWOJU HUMANISTYKI
}

\author{
Copyright $($ ) \\ Instytut Kultur Śródziemnomorskich i Orientalnych PAN \\ et les Auteurs \\ Warszawa 2018
}

ISSN 2084-6762

(avant $2011: 0079-3566$ )

e-ISSN 2449-9579

Version première en papier, imprimée en Pologne - 150 copies

Version électronique accessible sur http://www.etudesettravaux.iksiopan.pl

Édition: Polskie Towarzystwo Historyczne et Wydawnictwo Neriton, Warszawa

Conception générale de couverture : J. Iwaszczuk Photo de couverture : P. Moser (C) Schweizerisches Institut für Ägyptische Bauforschung und Altertumskunde in Kairo

(terre cuites d'Aswan/Syene) 


\section{Table des matières}

KAROL MYŚLIWIEC

$(E T=E t u d T r a v / 50) \times 30$

HASSAN Aglan

Hatshepsut and the Apis Race: New Quartzite Relief Fragments

from Dra' Abu el-Naga

Amgad Joseph

Divine Wrath in Ancient Egypt

Amgad Joseph

Pain Infliction, Inflictors and Healers in Egyptian Religious, Magical

and Literary Perceptions

MirosŁaW BarwiK

New Dipinti in the Birth Portico of the Hatshepsut Temple at Deir el-Bahari

KrzyszTOF BorysŁaWsKi, ANNA NiwiŃSKA, ANDRZEJ NiwiŃSKI,

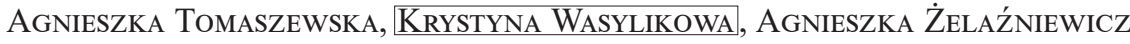

A Bulb of Narcissus on the Egyptian Mummy from University

of Wrocław Collection

LINDA CHAPON

Some Reliefs Representing the King in the Heb Sed Robe Discovered in the Henket-Ankh

Philippe Guillaume

Debunking the Latest Scenario on the Rise of the Pork Taboo

Mariola Hepa

A Clay Gladius Scabbard from Area 13c in the Ancient Roman Town of Syene

Emanuele E. Intagliata

Pinpointing Unrest at Palmyra in Early Islamic Period. The Evidence from Coin Hoards and Written Sources 
KATARZYNA KAPIEC

The Sacred Scents: Examining the Connection Between the ' $n t j w$ and $s f \underline{t}$ in the Context of the Early Eighteenth Dynasty Temples

DOMINIKA MAJCHRZAK

Remarks on the Iconographic Motif of the Birdman in Mesopotamian Glyptic Art of the Third Millennium BC

KAROLINA PAWLIK

Stone Artefacts from Late Roman Occupation Phases in Nea Paphos

ABRÉVIATIONS 
THE VOLUME IS PUBLISHED TO CELEBRATE

THE $50^{\text {TH }}$ ANNIVERSARY

OF THE

ÉTUDES ET TRAVAUX

ESTABLISHED IN 1966 